\title{
Leadership of Ece Principal in Growth Character Through Stifin Method in Kindergarten
}

\author{
Imron Arifin \\ Administrasi Pendidikan, Fakultas Ilmu Pendidikan \\ Universitas Negeri Malang \\ Imron.arifin.fip@um.ac.id
}

\author{
Ikhsan Gunadi \\ Administrasi Pendidikan, Fakultas Ilmu Pendidikan \\ Universitas Negeri Malang \\ ikhsangunadi@gmail.com
}

\begin{abstract}
Early Childhood Education (ECE) is the stage and stage of learning era of golden age. At this time the child experiencing the process of growing the most optimal, both cognitive and mental attitudes. For that required a quality learning process that is able to grow the character. The leadership of ECE heads influences the effectiveness of character education. One STIFIn method is believed to have a formulation in character education. The study used a qualitative approach, with a single case study design. The results showed that the principal in TK Plus Mutiara Ilmu, Pandaan was quite effective in interpersonal communication with the teacher. The principal implements a transactional leadership pattern that brings the teacher's moral imperative in applying the child's character development. Teachers with STIFIn methods are more open and have a positive attitude. Based on the STIFIn circulation theory, the principal has relatively good team, and is in a strong position. In addition supported by subordinates, it also effectively affects subordinates, in addition STIFIn methods are able to provide differences and effective changes in interpersonal communication to teachers and children in growth character.
\end{abstract}

Keywords-early childhood leadership, character growth, STIFIn method

\section{INTRODUCTION}

Since the mid-1990s the Government of Indonesia has begun to seriously respond to the existence of education for children of early ages by making policies set forth in Law No. 20 of 2003 on National Education System. This certainly takes into consideration many aspects so that the existence of this long-standing education has gained a response and is part of the national education system. Early childhood education is considered the most strategic, because it determines the quality of human resources and nation leaders in the next 30-40 years. (Sonhadji, 2014). Considering that, it becomes very important for early childhood as the first place of character development of children that will determine in the process of its continuation.

The challenges of early childhood education in the future face obstacles, called Herawati (2016), covering: (1) teacher education level where only $23.06 \%$ are educated strata-1
(S1), Meanwhile, according to National Education Standards should be ECE teachers both formal and non formal minimum S1 PAUD (S1 ECE), psychology, or education; (2) the issue of the quality of ECE programs and institutions; (3) still one-third of children aged 3-6 years who have not received ECD services; (4) family involvement that has not been aligned with ECE institution. Whereas early childhood is the work to build the foundation of the nation and grow children develop. So all parties, including parents, should support the effort; (5) early childhood learning that should be $80 \%$ attitude building, nowadays it focuses on academic reading-write-counting learning.

Seeing the latest problems and challenges requires leadership leadership that can foster children's character from an early age. Leadership is the ability to influence a group of members to work to achieve goals and objectives. Hughes, Ginnet \& Curphy (2012) defines leadership as the process of influencing an organized group to achieve group goals (Arifin, 2010). Yukl (1981) defines "Leadership has been defined in terms of individual traits, behavior, influence over other people, interaction patterns, role relationships, occupation of an administrative position, and perception of other regarding legitimacy of influence." , Jillian Rodd (2006) gives the definition: "Leadership is understood as a share process where effective leaders draw on a range of strategies to achieve positive and ethical outcomes for members of the group or the organization."

Leadership is also interpreted as (1) science and art, and (2) rational and emotional. Interpreted science as well as art emphasizes that the issue of leadership can look back in terms of theoretical and practical aspects. Likewise, when leadership involves the rational and emotional side of human experience. Leadership includes a number of actions and influences based on reason and logic and inspiration and the calling of the soul (Hughes, Ginnet, \& Curphy, 2012).

Effective leaders are characterized by communication skills as the most important and complex aspects of interacting with others. Communication will affect someone, both known and unknown at all (Arifin, 2010). This type of interpersonal communication is a communication process 
that is viewed from perception of others (interpersonal). Interpersonal communication through face-to-face meetings, allowing each culprit to capture the reactions of others directly, either verbally or non-verbally (Morissan, 2013).

Effective interpersonal communication can also be explained from the perspective of The 5 Inevitable Laws of Effective Communication, namely Respect, Empathy, Audible, Clarity, and Humble (REACH). This is relevant to the principle of interpersonal communication, ie as an effort to gain attention, recognition, love, sympathy, and positive response from others (Suranto, 2011). Meanwhile, Devito (2011), put forward five positive attitudes that need to be considered when someone is doing interpersonal communication. The five positive attitudes, including indicators: (1) openness; (2) empathy; (3) supportiveness; (4) positiveness; And (5) equality.

The declaration of strengthening character education by Ministry of Education Affairs, Indonesia Republic brings great hope about the change of constructive and substantive educational paradigm. Constructive because forming human character is necessary human being creative and critical and will become trend setter for environment. Human character formation process is not a short process but requires time, strategy, finance and integrated system that can support character education into a school culture and family culture

Stage of education and character planting at least through four stages. First, Knowing, at this stage children are given knowledge about good and bad behavior and norms that exist in society. Secondly, reasoning provides an understanding of the child that raises awareness and can feel. Third, feeling, feel the impact when children do good both at school and at home. Fourth, acting where the child takes action as a manifestation of knowledge, understanding and feelings of children so that will be internalized in the child's personality. The process of internalization of character education can not be done if it does not involve parents who have a major contribution in child growth, especially at the early childhood stage.

Early childhood education is one of the many developed strategic programs Wortham (2005) states "Assessment should involve the child and Family". That is, the identification of the needs of early childhood education should involve parents and nursemaid as a source of information because many children spend time at home. Pre-school, kindergarten and early primary education are more understanding of the needs and abilities of children in learning but it will be difficult if at the beginning of the lesson do not get information from parents about children's habits, child preferences and the ability of children who conspicuous. So the information obtained at home is developed in schools. School mother also serves as a means of communication between parents and institutions early childhood and then after the children get character education can be developed and implemented at home
ECE is part of lifelong education, as a concept that has been popularized by UNESCO with the term "Life Long Education". This is in line with the Islamic teachings on lifelong education. The concept of Islam on this subject which has been popularized by UNESCO has been a guide in elevating human dignity, including Indonesian people. Therefore, the children of this nation need to get coaching from an early age through education so that they will not be left behind by other nations in the world (Mulyasa, 2012).

Character education for early childhood has a higher meaning than moral education because it not only deals with true-false issues but how to inculcate habits about good behaviors in life, so that children have awareness, and a high understanding, and a concern and commitment to apply Virtue in everyday life. Since character is a natural trait for early childhood to respond to the situation morally, it must be manifested in concrete action through habituation to behave kindly, honestly, responsibly, and respectfully to others.

Character education requires the involvement of stakeholders including the components that exist within the education system itself, namely: curriculum, lesson plans, learning process, assessment mechanism, relationship quality, learning management, school management, selfdevelopment of learners, empowerment of infrastructure, Financing, and work ethic of all citizens and the school environment. The success of character education for early childhood is dependent on the presence or absence of awareness, understanding, awareness, and commitment of various parties to education.

The concept of STIFIn is built by the theories of experts in each field which then elaborated. There are three terrors that form the basis of the STIFIn concept, namely: (1) Basic Function Theory of pioneering analytical psychology Carl Gustav Jung who said that there are four basic human functions namely Sensing, Thinking, Feeling, Intuition. Of the four basic functions, only one of them is dominant; (2) The Hemisphere Theory of a neuroscientist Ned Hermann who divides the brain into four quadrants of the left and right limbic, as well as the left and right cerebral; And (3) Brain Strata Theory of Triune (three in one brain) from neuroscientist, Paul MacLean who divides the human brain based on the evolutionary results: the human brain, mammals, and reptiles (Hunt \& Love, 2002; Buzan, 2005).

The STIFIn concept explains many things, proving that this concept has new synthesis results. STIFIn was developed based on seven theories (Poniman, Nugroho, \& Azzaini, 2003); (Poniman, 2015), among others: (1) The theory of crossing as superior and inferior in one package. This theory explains the cross-linkage of intelligent Intuiting and Intuiting-Thinking-Feeling interactions; (2) The theory of slicing equations (between the quadrant and diagonal poles), ie the interconnectedness of each other, such as: Thinking - Intuiting has similarities in investigative work and analysis. In addition, compiled Sensing - Feeling in 
terms of social relationships; (3) Theory of a five-sided social relation (STIFIn Circulation Theory). STIFIn describes the interaction of social interaction, in two conditions, namely (a) mutual support, and (b) mutual conquering relationships; (4) The theory of alignment of body metabolism based on the machine of his intelligence. STIFIn explains the biological condition of a person in harmony between the intelligence engine with the metabolism elements of each MK, namely: (a) Sensingorgan of the digestive system (stomach); (b) Thinking-organ excretion system (kidney); (c) Intuiting-organ synthesis system (liver) and nervous system; (d) respiratory / respiratory organisms; And (e) Instinct-organ of the circulatory system and the center of equilibrium; (5) Calibration theory based on intelligence machine. STIFIn reveals how each intelligence engine releases its pressure and regains its best state; (6) Genetic theory according to the machine of intelligence. Based on intelligence machines and intelligence drives, STIFIn groups personality genetics or intelligences into nine groups, namely: (a) Introverted SiSensing; (b) Se-Sensing extrovert; (c) Ti-Thinking introverts; (d) Te-Thinking extrovert; (e) Ii-Intuiting introvert; (f) Ie-Intuiting extrovert; (g) Fi-Feeling introvert; (h) Fe-Feeling extrovert; And (i) In-Instinct; And (7) the theory of the genetic strata. The concept of dividing STIFIn ranks the sequence against human genetics. Here is the sequence of genetic strata from highest to low, namely: (a) gender; (b) machine of intelligence; (c) drive of intelligence; (d) hardware capacity; and (e) blood type.

\section{RESEARCH METHODS}

Research conducted by conducting experiments to the principal and some teachers. Teachers are divided according to their class groups, namely the teachers of KB1 (KB group 1), A1 (TK A group 1), A2 (TK A group 2), KB2 (KB group 2 ), B1 (TK B group 1). And B2 (TK B group 2). To the principal and teachers of KB1, A1 and B1 will be treated by STIFIn method, ie by doing a test to know the PG of each teacher. Another treatment is to introduce STIFIn concepts to principals and teachers, including the effectiveness of communicating with after knowing each PG (teacher and principal).

Meanwhile, teachers of KB2, A2 and B2 will not be treated with the STIFIn method, meaning that the teachers will not recognize each other's PG, so the principal and teacher do not know it. To this group of teachers will not be introduced about the concept of STIFIn, as well as PG owned by the principal. So it will be left natural in terms of interacting and communicating.

While the principal and the two groups of teachers are also distributed questionnaires / questionnaires and interviews to find out more about effective communication patterns developed so far including after understanding the concept and method STIFIn (teacher group 1).

\section{A. Personality genetic examination \\ From the observations made by researchers during being} in TK Plus Mutiara Ilmu Pandaan, and conducted examination of teachers, then obtained data according to the table. 1 as follows.

\section{TABLE I. LIST OF INTELLIGENCE MACHINES - PERSONALITY GENETIC}

\begin{tabular}{ccc}
\hline Responder & Position & Personality Genetic \\
\hline Headmaster & headmaster & Sensing extrovert (Se) \\
\hline Teacher 1 & Teacher KB-A & Sensing Introvert (Si) \\
\hline Teacher 2 & Teacher TK - A1 & Instinct (In) \\
\hline Teacher 3 & Teacher TK - B1 & Thinking Introvert (Ti) \\
\hline Teacher 4 & Teacher KB-B & unknown \\
\hline Teacher 5 & Teacher TK - A2 & unknown \\
\hline Teacher 6 & Teacher TK - B2 & unknown \\
\hline
\end{tabular}

Based on the results of examination on each principal, teacher KB1, teacher A1 and teacher B1 which can be seen in table 2 the following matrix relationship.

\section{TABLE II. MATRIX OF MK / PG RELATIONSHIP BETWEEN PRINCIPAL AND TEACHER}

\begin{tabular}{ccccc}
\hline & $\begin{array}{c}\text { Headmaster } \\
(\mathbf{S e})\end{array}$ & $\begin{array}{l}\text { Teacher } \\
\mathbf{K B}_{\mathbf{1}}(\mathbf{S i})\end{array}$ & $\begin{array}{l}\text { Teacher } \\
\mathbf{A}_{\mathbf{1}}(\mathbf{I n})\end{array}$ & $\begin{array}{l}\text { Teacher } \mathbf{B}_{\mathbf{1}} \\
(\mathbf{T i})\end{array}$ \\
\hline $\begin{array}{c}\text { Headmaster } \\
(\text { Se })\end{array}$ & -- & Same & Conquer & Mendukung \\
\hline $\begin{array}{c}\text { Teacher KB } \mathbf{B}_{\mathbf{1}} \\
(\mathbf{S i})\end{array}$ & Sama & -- & Conquer & Promote \\
\hline $\begin{array}{c}\text { Teacher } \mathbf{A}_{\mathbf{1}} \\
(\text { In) }\end{array}$ & Conquered & Conquered & -- & Supported \\
\hline $\begin{array}{c}\text { Teacher } \mathbf{B}_{\mathbf{1}} \\
(\mathbf{T i})\end{array}$ & Supported & Supported & Promote & - \\
\hline
\end{tabular}

From the above matrix, the principal's position is in a relatively strong area because in addition to being supported by A1 teachers and supporting teachers B1 is also a "conqueror" for KB1 teachers. This means, the principal (Se) must play some positions as a leader. First, the principal becomes an equal partner of the KB1 (Si) teacher. Second, directing and mentoring teachers A1 (In), and thirdly, to teacher B1 (Ti), the principal becomes a facilitator and mentor for the teacher she supports.Thus, for teachers already known to each MK / PG, the principal must adjust the pattern of interpersonal communication to each teacher of his various MK / PG.

\section{B. Intake of Interpersonal Communication Data}

From interviews and interviews and questionnaires distributed to principals and teachers with results as Table 3 below. 
TABLE III. ACCUMULATED PRINCIPAL DATA IN STIFIN TREATMENT

\begin{tabular}{llccccc}
\hline No & Aspect & $\begin{array}{c}\text { Strongl } \\
\text { y agree }\end{array}$ & $\begin{array}{c}\text { Agre } \\
\mathbf{e}\end{array}$ & $\begin{array}{c}\text { Ordinar } \\
\mathbf{y}\end{array}$ & $\begin{array}{c}\text { diasgre } \\
\mathbf{e}\end{array}$ & $\begin{array}{c}\text { Strongl } \\
\mathbf{y} \\
\text { diasgree }\end{array}$ \\
\hline $\mathbf{1}$ & Openess & $31 \%$ & $\mathbf{4 6 \%}$ & $23 \%$ & $0 \%$ & $0 \%$ \\
\hline $\mathbf{2}$ & Emphaty & $23 \%$ & $\mathbf{3 8 \%}$ & $\mathbf{3 8 \%}$ & $0 \%$ & $0 \%$ \\
\hline $\mathbf{3}$ & Supportiness & $23 \%$ & $0 \%$ & $31 \%$ & $\mathbf{4 6 \%}$ & $0 \%$ \\
\hline $\mathbf{4}$ & $\begin{array}{l}\text { Possitivenes } \\
\text { s }\end{array}$ & $39 \%$ & $\mathbf{5 0 \%}$ & $11 \%$ & $0 \%$ & $0 \%$ \\
\hline $\mathbf{5}$ & Equality & $\mathbf{6 1 \%}$ & $33 \%$ & $6 \%$ & $0 \%$ & $0 \%$ \\
\hline $\begin{array}{l}\text { Percentage of } \\
\text { data distribution }\end{array}$ & $\mathbf{3 7 \%}$ & $35 \%$ & $20 \%$ & $8 \%$ & $0 \%$ \\
\hline
\end{tabular}

The data in Table 3, generally indicates that the principal is relatively open in communicating with $37 \%$. In addition the principal is considered quite open (46\%), empathy to his subordinates $(38 \%)$, and always positive $(50 \%)$. The principal also has parallels with the teachers in interpersonal communication.

However, the principal has no supportive attitude to subordinates in interpersonal communication. As for teachers, in the treatment group obtained the following table 4 below.

\section{TABLE IV. RESULTS OF TEACHER DATA IN STIFIN TREATMENT}

\begin{tabular}{ccccccc}
\hline No. & Aspect & $\begin{array}{c}\text { Strongly } \\
\text { agree }\end{array}$ & agree & Ordinary & diasgree & $\begin{array}{c}\text { Strongly } \\
\text { diasgree }\end{array}$ \\
\hline $\mathbf{1}$ & Openness & $\mathbf{4 6 \%}$ & $36 \%$ & $10 \%$ & $8 \%$ & $0 \%$ \\
\hline $\mathbf{2}$ & Emphaty & $33 \%$ & $\mathbf{4 4 \%}$ & $15 \%$ & $8 \%$ & $0 \%$ \\
\hline $\mathbf{3}$ & Supportiness & $10 \%$ & $\mathbf{4 1 \%}$ & $33 \%$ & $15 \%$ & $0 \%$ \\
\hline $\mathbf{4}$ & Possitiveness & $37 \%$ & $\mathbf{4 8 \%}$ & $7 \%$ & $7 \%$ & $0 \%$ \\
\hline $\mathbf{5}$ & Equality & $\mathbf{5 0 \%}$ & $28 \%$ & $7 \%$ & $15 \%$ & $0 \%$ \\
\hline $\begin{array}{r}\text { Percentage of data } \\
\text { distribution }\end{array}$ & $36 \%$ & $\mathbf{3 9 \%}$ & $14 \%$ & $11 \%$ & $0 \%$ \\
\hline
\end{tabular}

The data above shows that the tendency of teachers who already get an explanation of the concept of STIFIn has a positive value. In the openness aspect (openness) which $46 \%$ indicates that the teacher is very open in communicating. Teachers also always think positively (possitiveness) as much as $48 \%$, and tend to equalize as much as $50 \%$ in interpersonal communication. While in the attitude of support (41\%) and have a sense of empathy (41 $\$ \%$ ) in interpersonal communication, which it means quite well.

The group of teachers who are not treated, obtained data as in table 5 below.

\section{TABLE V. RESULTS OF TEACHER DATA OUTSIDE STIFIN TREATMENT}

\begin{tabular}{clccccc}
\hline No. & Aspect & $\begin{array}{c}\text { Strongl } \\
\text { y agree }\end{array}$ & $\begin{array}{c}\text { Agre } \\
\mathbf{e}\end{array}$ & $\begin{array}{c}\text { Ordinar } \\
\mathbf{y}\end{array}$ & $\begin{array}{c}\text { diasgre } \\
\mathbf{e}\end{array}$ & $\begin{array}{c}\text { Strongly } \\
\text { diasgree }\end{array}$ \\
\hline $\mathbf{1}$ & Openess & $\mathbf{3 8 \%}$ & $33 \%$ & $21 \%$ & $5 \%$ & $3 \%$ \\
\hline $\mathbf{2}$ & Emphaty & $28 \%$ & $\mathbf{4 1 \%}$ & $26 \%$ & $3 \%$ & $3 \%$ \\
\hline $\mathbf{3}$ & $\begin{array}{l}\text { Supportin } \\
\text { ess }\end{array}$ & $13 \%$ & $\mathbf{4 1 \%}$ & $31 \%$ & $13 \%$ & $3 \%$ \\
\hline $\mathbf{4}$ & $\begin{array}{l}\text { Possitiven } \\
\text { ess }\end{array}$ & $\mathbf{4 8 \%}$ & $35 \%$ & $17 \%$ & $0 \%$ & $0 \%$ \\
\hline $\mathbf{5}$ & Equality & $37 \%$ & $\mathbf{5 0 \%}$ & $13 \%$ & $0 \%$ & $0 \%$ \\
\hline $\begin{array}{l}\text { Percentage of } \\
\text { data distribution }\end{array}$ & $34 \%$ & $\mathbf{4 0 \%}$ & $20 \%$ & $4 \%$ & $1 \%$ \\
\hline
\end{tabular}

The data above shows that $40 \%$ of the overall data has a good tendency toward the five aspects of interpersonal communication. The openness aspect of teachers reaches $38 \%$, emphaty $41 \%$, supportiveness $41 \%$, positive attitude (possitiveness) reaches $48 \%$, and has $50 \%$ equality.

\section{Results of Growth Assessment of Student Character}

From the results of treatment to two different groups of teachers, then carried out the observation of the learning process students in the classroom. In this section, observations are made by focusing on two independent character values and communication.

Observations were made on the $\mathrm{KB}$ classes (two classes), TK A (two classes) and TK B (two classes) where each teacher taught. The following is a table $6 a$ and $6 \mathrm{~b}$ on the comparison of assessment results in each class.

TABLE VIA. COMPARISON OF TREATMENT CLASSES AND NON SELF-TREATMENT VALUES

\begin{tabular}{|c|c|c|c|c|c|c|c|c|c|}
\hline \multirow[t]{2}{*}{$\begin{array}{l}\text { Gro } \\
\text { up } 1\end{array}$} & \multicolumn{2}{|c|}{$\begin{array}{c}\text { Above } \\
\text { Average }\end{array}$} & \multicolumn{2}{|c|}{$\begin{array}{c}\text { Below } \\
\text { Average }\end{array}$} & \multirow[t]{2}{*}{$\begin{array}{l}\text { Gro } \\
\text { up } 2\end{array}$} & \multicolumn{2}{|c|}{$\begin{array}{c}\text { Above } \\
\text { Average }\end{array}$} & \multicolumn{2}{|c|}{$\begin{array}{c}\text { Below } \\
\text { Average }\end{array}$} \\
\hline & $\begin{array}{c}\text { Amou } \\
n t\end{array}$ & $\%$ & $\begin{array}{c}\text { Amou } \\
\text { nt }\end{array}$ & $\%$ & & $\begin{array}{c}\text { Amou } \\
\text { nt }\end{array}$ & $\%$ & $\begin{array}{c}\text { Amou } \\
\text { nt }\end{array}$ & $\%$ \\
\hline$K_{B_{1}}$ & 4 & 5 & 3 & 4 & $\mathrm{~KB}_{2}$ & 3 & 4 & 4 & 5 \\
\hline & & 7 & & 3 & & & 3 & & 7 \\
\hline TK & 7 & 7 & 3 & 3 & TK & 6 & 6 & 4 & 4 \\
\hline $\mathbf{A}_{1}$ & & 0 & & 0 & $\mathbf{A}_{2}$ & & 0 & & 0 \\
\hline TK & 4 & 4 & 5 & 5 & TK & 3 & 3 & 6 & 6 \\
\hline $\mathbf{B}_{1}$ & & 4 & & 6 & $\mathbf{B}_{2}$ & & 3 & & 7 \\
\hline
\end{tabular}

TABLE VIB. COMPARISON OF TREATMENT CLASS AND NON TREATMENT OF COMMUNICATION

\section{VALUE}

\begin{tabular}{|c|c|c|c|c|c|c|c|c|c|}
\hline \multirow[t]{2}{*}{$\begin{array}{l}\text { Gro } \\
\text { up } 1\end{array}$} & \multicolumn{2}{|c|}{$\begin{array}{c}\text { Above } \\
\text { Average }\end{array}$} & \multicolumn{2}{|c|}{$\begin{array}{c}\text { Below } \\
\text { Average }\end{array}$} & \multirow[t]{2}{*}{$\begin{array}{l}\text { Gro } \\
\text { up } 2\end{array}$} & \multicolumn{2}{|c|}{$\begin{array}{c}\text { Above } \\
\text { Average }\end{array}$} & \multicolumn{2}{|c|}{$\begin{array}{c}\text { Below } \\
\text { Average }\end{array}$} \\
\hline & $\begin{array}{c}\text { Amou } \\
n t\end{array}$ & $\%$ & $\begin{array}{c}\text { Amou } \\
n t\end{array}$ & $\%$ & & $\begin{array}{c}\text { Amou } \\
\text { nt }\end{array}$ & $\%$ & $\begin{array}{c}\text { Amou } \\
\text { nt }\end{array}$ & $\%$ \\
\hline $\mathbf{K B}_{1}$ & 4 & $\begin{array}{l}5 \\
7\end{array}$ & 3 & $\begin{array}{l}4 \\
3\end{array}$ & $\mathbf{K B}_{2}$ & 3 & $\begin{array}{l}4 \\
3\end{array}$ & 4 & $\begin{array}{l}5 \\
7\end{array}$ \\
\hline $\begin{array}{l}\text { TK } \\
A_{1}\end{array}$ & 3 & $\begin{array}{l}3 \\
0\end{array}$ & 7 & $\begin{array}{l}7 \\
0\end{array}$ & $\begin{array}{l}\text { TK } \\
\mathbf{A}_{2}\end{array}$ & 6 & $\begin{array}{l}6 \\
0\end{array}$ & 4 & $\begin{array}{l}4 \\
0\end{array}$ \\
\hline $\begin{array}{l}\text { TK } \\
\text { B }_{1}\end{array}$ & 7 & $\begin{array}{l}7 \\
8\end{array}$ & 2 & $\begin{array}{l}2 \\
2\end{array}$ & $\begin{array}{l}\text { TK } \\
\text { B }_{2}\end{array}$ & 3 & $\begin{array}{l}4 \\
4\end{array}$ & 6 & $\begin{array}{l}5 \\
6\end{array}$ \\
\hline
\end{tabular}


From the table above shows that, in general, the comparison between group / group 1 and group / group 2 in terms of achievement above the average standard of independent ability, each of $57 \%$ (Group 1) versus $45 \%$ (Group 2) . It can be seen in more detail where each of the highest achievement is on Group $1 \mathrm{~KB} 1=57 \%$; TK A1 = 70\%; And TK B1 $=44 \%$. While the lowest achievement (low student score) in Group 1 occurred in the B1 TK class of $56 \%$, while on the same level in Group $267 \%$. The highest attainment (high student scores) was achieved by $60 \%$ of TK A2 class, where there was a difference of $10 \%$ compared to $70 \%$ of TK A1. From the data it can be said that the growth of independent characters tend to occur in Group 1, the group that was given the influence STIFIn method.

While on communication skills, it can be seen on the whole that the comparison between Group 1 and Group 2, each of 55\% (Group 1) and 49\% (Group 2). When viewed further, then each high value achievement is in Group 1 is $\mathrm{KB} 1=57 \%$; $\mathrm{TK} \mathrm{A} 1=30 \%$; And $\mathrm{TK} \mathrm{B} 1=78 \%$. The attainment of low grades occurred in $70 \%$ of TK A1 classes, and only $40 \%$ of low-grade students in the A2 A $60 \%$ high grade group is the largest in Group 2). While the achievement of high value in Group 1 is in the class of TK B1 sebear $78 \%$. From the data and description it can be said that the character of communication skills for students tends to grow better in the class in Group 1 whose teachers have been treated with the STIFIn method.

From the above phenomenon affirms that mutually open and mutually recognizable communication, it will facilitate a person to act and take strategic and technical decisions appropriately. This is what happens after the teachers who already know each other including the leader (principal) so that will facilitate the teacher in carrying out learning to his students.

\section{IV.CONCLUSION}

From the above description can be concluded that the principal in TK Plus Mutiara Pandaan Science quite effective in interpersonal communication with teachers. The principal implements a transactional leadership pattern that brings the teacher's moral imperative in applying the child's character development.

Teachers with STIFIn method are more open and have a better positive attitude compared with unknown teachers personality with STIFIn method. The ability of teachers to understand the potential behavior of children will be easy to approach and treatment to each child in the right way so that children are effective in playing while learning with the growth of character.

Based on the STIFIn circulation theory, the principal has relatively good team, and is in a strong position. Besides supported by subordinates, it also effectively affects subordinates, in addition STIFIn method is able to provide differences and effective changes in interpersonal communication to teachers and children with attitude open.

Principals should use the STIFIn concept to facilitate their leadership process in school, by conducting checks to find out the personality and intelligence of each teacher. So that will provide an open-endedness to each other that makes the understanding of each personality is known by the principal and other teachers, and eventually will be achieved effective interpersonal communication according to the concept of Johari Window.

To facilitate the learning process and achieve effective learning, schools can perform tests / tests with STIFIn methods to be done such as: class mapping based on the intelligence group of each student, choosing the right teacher so that the teacher style can occur the same as student learning style. Teachers can make well prepared lesson plans, and so on.

\section{REFERENCE}

[1] Andang. (2014). Manajemen \& Kepemimpinan Kepala Sekolah. Sleman: Ar Ruzz.

[2] Arifin, I. (2010). Kepemimpinan Kepala Sekolah dalam Mengelola Sekolah Berprestasi: Studi Multi Kasus pada MIN Malang I, MI Mamba'ul Ulum, dan SDN Ngaglik I Batu Malang. Yogyakarta: Aditya Media

[3] Arifin, I. (2012). Kepemimpinan Kepala PAUD dalam Mengimplementasikan Pembelajaran Sentra: Studi Kasus PAUD Unggulan Nasional Anak Saleh Malang. Yogyakarta: Aditya Media.

[4] BERITASatu.com. (2016). Delapan Masalah PAUD di Indoenesia (http://www.beritasatu.com/pendidikan/353926-inidelapan-masalah-paud-di-indonesia.html). Jakarta: BERITASatu.com. Diambil kembali dari http://www.beritasatu.com/pendidikan/353926-ini-delapanmasalah-paud-di-indonesia.html

[5] Buzan, T. (2005). The Mind Set: Use Your Head, Use Your Memory, The Speed Reading Book and The Mind Map Book. London: BBC Worldwide.

[6] Crow, L., \& Crow, A. (1991). Educational Psychology. San. Antonio: Texbook of Advanced Education Psychology.

[7] Danim, \& Suparno. (2009). Manajemen dan Kepmimpinan Transformasional Kekepalasekolahan. Jakarta: Rineka Cipta.

[8] Devito, J. (2011). Komunikasi Antarmanusia. Tanggerang Selatan: Karisma Publishing Group.

[9] Djaali. (2009). Psikologi Pendidikan. Jakarta: PT Bumi Aksara.

[10] Hardjana, A. M. (2003). Komunikasi Intrapersonal \& Komunikasi Interpersonal. Yogyakarta: Penerbit Kanisius.

[11] Helmawati. (2015). Mengenal dan Memahami PAUD. Bandung: PT Remaja Rosdakarya.

[12] Hughes, R. L., \& Ginnet, R. C. (2012). Leadership: Memperkaya Pelajaran dan Pengalaman. (P. I. Izzati, Penerj.) Jakarta: Salemba Humanika.

[13] Hunt, E., \& Love, T. (2002). How Good Can Memory Be? (A. Melton, \& E. Martin, Penyunt.) Coding Processes in Human Memory, 237-260.

[14] Morissan. (2013). Teori Komunikasi Individu hingga Massa. Jakarta: Kencana.

[15] Mulyana, R. (2004). Mengartikulasikan Pendidikan Nilai. Bandung: Alfabeta CV.

[16] Mulyasa, H. (2012). Manajemen PAUD. Bandung: PT Remaja Rosdakarya.

[17] Mustaqim. (2005). Psikologi Pendidikan. Yogyakarta: Pustaka Pelajar.

[18] Piaget, J., \& Inhelder, B. (2010). Psikologi Anak (Cet. 1 ed.). (M. Jannah, Penerj.) Yogyakarta: Pustaka Pelajar. 
[19] Poniman, F. (2015). Penjelasan Hasil Tes STIFIn: The Nine of Genetic Personality. Jakarta: Yayasan STIFIn.

[20] Poniman, F., Nugroho, I., \& Azzaini, J. (2003). Kubik Leadership. Bandung: Mizan.

[21] Robbins, S. P. (2006). Organizational Behavior: Concepts, Controversies, and Applications. Englewood Clift, New Jersey: Prentice Hall.

[22] Rodd, J. (2006). Leadership in Early Childhood (3rd ed.). Crows Nest, NSW: Allen \& Unwin.

[23] Sonhadji, A. (2014). Manusia, Teknologi dan Pendidikan: Menuju Peradaban Baru. Malang: UM Press.

[24] Suranto, A. (2011). Komunikasi Interpersonal. Yogyakarta: Graha Ilmu.

[25] Wortham, S. C. (2005). Assesment in Early Childhood Education. Columbus, Ohio: Merill, in Prentice Hall.

[26] Yukl, G. A. (1981). Leadership In Organizations. Englewood Cliffs, NJ: Prentice Hall, Inc. 